\title{
Critics attack hasty review of quake prediction efforts
}

Tokyo. A rushed internal review of Japan's earthquake prediction programme in the light of the Kobe disaster has stimulated several leading Japanese scientists to call for a new external assessment of the country's earthquake prediction programme.

The review was carried out by the earthquake prediction subcommittee of the Geodetic Council - an advisory body to the Ministry of Education, Science and Culture. The council approved and submitted the subcommittee's recommendations to the ministry last week.

But Hideki Shimamura of Hokkaido University's Laboratory for Ocean Bottom Seismology, who is a member of Japan's Geodetic Council's earthquake prediction subcommittee, complains that the review "lacks modesty". He says that it makes no attempt to explain the present status and limitations of earthquake prediction to the general public.

Furthermore, he says it was agreed by researchers and government officials involved that there should be unification of the activities of agencies involved in earthquake prediction, possibly under the umbrella of an "earthquake agency".

But, according to Shimamura, apart from agreeing to pool data at the Japan Meteorological Agency (JMA), all discussion of unification was "killed" by Harumi Aoki, chairman of the subcommittee, on the grounds that it was "too early" to discuss such matters and there was "no time".

Following the Kobe disaster, government agencies and ministries involved in the prediction programme, which employs about 500 researchers on an annual budget of more than $¥ 10$ billion (US $\$ 120$ million), called for an unscheduled review of the programme in the hope of increasing its budget (see Nature 374, 205; 1995).

In a departure from present practice, the report of the review committee calls on the JMA to act as a central agency for the collection of all data on earthquakes, including microearthquakes. Until now, microearthquakes have been the exclusive domain of university researchers.

The report also calls for more research on active faults, such as the one that caused the Kobe earthquake. In other respects, its conclusions are similar to a lengthy review of the programme carried out in 1992 and 1993, which called for only minor adjustments in the 30 -year-old programme (see Nature 364, 370; 1993).

But in addition to Shimamura, some members of the subcommittee are also upset by the way the recommendations were prepared. A draft was drawn up by
Tomowo Hirasawa of Tohoku University, one of the senior leaders of the programme, with a small drafting committee.

The committee included Aoki and a few select members of the 20-man earthquake prediction subcommittee. But despite "heated discussions" at the subcommittee's final meeting, changes to the draft were only "cosmetic" says Shimamura.

Aoki dismisses Shimamura's criticisms as "emotional" and "selfish", while Yukiko Hirakawa of the Ministry of Education, who has administrative responsibility for the programme, says she cannot believe a member of the subcommittee made such criticisms.

Aoki claims to have made great personal efforts to explain earthquake prediction to the general public, for example through the publication in 1990 of a pamphlet entitled "Earthquake Prediction Now". $\mathrm{He}$ says that both critics of the programme and young researchers have failed to come forward with concrete proposals for reform.

But Shimamura is not alone in his criticisms. Seiya Uyeda, a professor of geotectonics at both Tokai University and Texas A\&M University in the United States, and a member of the Geodetic Council, wrote to the minister of education during the review process stressing the need for a more thorough review. In particular, he urged the substantial involvement of scientists outside the programme covering a wide spectrum of Earth sciences.

Yoshihide Kozai, emeritus professor of the National Astronomical Observatory, and chairman of the Geodetic Council, who was responsible for submitting the recommendations to the Ministry of Education, says that he also sees the need for an external review of the programme.

Kozai says he has called for such a review on several occasions, but that it is not yet clear when it will be carried out, or what form it will take. Nevertheless, he feels that the present plan for the programme is better than the previous one. In particular, he points to the decision to collect all data centrally at the JMA as a significant step forward.

There is considerable disagreement, however, among members of the subcommittee about what the decision regarding JMA really means. Some see it as a move to reduce the heavy and monotonous work of collecting data on 'microquakes' at universities. Others are determined that universities should maintain a central role in monitoring such earthquakes.

David Swinbanks

\section{Protein institute gets a reprieve - and a new role}

Tokyo. Japan's generously funded Protein Engineering Research Institute (PERI) in Osaka is to get a second lease of life, under the new name - and expanded scientific goals - of the Biomolecular Engineering Research Institute (BERI).

PERI is one of a new breed of semi-private institutes jointly funded by private industry and the Japan Key Technology Center - known as Japan Key-TEC - a semi-governmental organization supported by dividends of government-held shares in the telecommunications company Nippon Telegraph and Telephone Corporation, which was privatized in 1985.

These institutes provide an unusual research environment for Japan. Scientists are given freedom to carry out basic research - much as they would be in a university - but are also provided with exceptionally good facilities that are comparable to, if not better than, those in private industry.

PERI is a small institute with about 60 researchers, drawn from universities and industry. Since its establishment in 1986, it has received more than $¥ 17$ billion (US\$210 million), 70 per cent coming from Japan Key-TEC, and the rest from 14 companies, including Kyowa Hakko and Takeda Chemical Industries.

The institute has established a relatively strong reputation in protein research. But it was due to close down next March - ten years after it was founded - under the rules of the Japan Key-TEC system which limit the life of institutes to ensure that they do not become entrenched in a particular line of research.

PERI will now be reborn as BERI, and will receive another $¥ 15$ billion in funds over 8 years, provided jointly by Japan KeyTEC and an expanded consortium of 18 companies. These include several newcomers - Japan Tobacco, Hitachi and Hoechst Japan, and the pharmaceutical companies Sankyo, Shionogi, Tanabe and Yamanouchi.

BERI was formally established as a corporation on 28 March. It is in the same building as PERI until the latter ceases to exist next year. At that time, Yoshiro Shimura, a biophysicist from Kyoto University, will take over as head of the new institute, and about half of 20 leading researchers of the former PERI will be replaced.

PERI has concentrated its research efforts on determining the structure of proteins. BERI will expand this goal to look in addition at lipids, sugars and nucleic acids; it will also attempt to establish their biological function as well as their structure. 